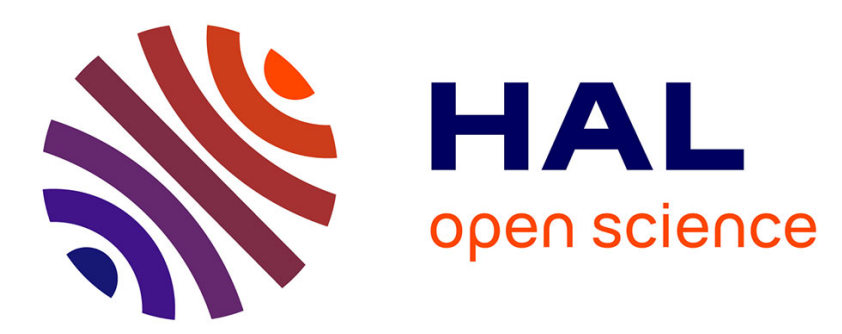

\title{
Effect of Additions and Oxygen Partial Pressure on the Electromagnetic Properties of High Frequency MnZn Ferrites
}

\author{
A. Znidarsic, I. Feriti, M. Drofenik
}

\section{- To cite this version:}

A. Znidarsic, I. Feriti, M. Drofenik. Effect of Additions and Oxygen Partial Pressure on the Electromagnetic Properties of High Frequency MnZn Ferrites. Journal de Physique IV Proceedings, 1997, 07 (C1), pp.C1-115-C1-116. 10.1051/jp4:1997135 . jpa-00255082

\section{HAL Id: jpa-00255082 https://hal.science/jpa-00255082}

Submitted on 1 Jan 1997

HAL is a multi-disciplinary open access archive for the deposit and dissemination of scientific research documents, whether they are published or not. The documents may come from teaching and research institutions in France or abroad, or from public or private research centers.
L'archive ouverte pluridisciplinaire HAL, est destinée au dépôt et à la diffusion de documents scientifiques de niveau recherche, publiés ou non, émanant des établissements d'enseignement et de recherche français ou étrangers, des laboratoires publics ou privés. 


\title{
Effect of Additions and Oxygen Partial Pressure on the Electromagnetic Properties of High Frequency MnZn Ferrites
}

\author{
A. Znidarsic, I. Feriti and M. Drofenik* \\ Stegne 29, 1000 Ljubljana, Slovenia \\ * Jozef Stefan Institute, Jamova 39, 1001 Ljubljana, Slovenia
}

\begin{abstract}
The effect of dopant and low oxygen partial pressure during sintering on the magnetic properties of MnZn ferrites for use in high frequency power supplies was studied. A low partial pressure of oxygen in the sintering atmosphere and a proper temperature profile during sintering decrease the average grain size, while the dopant, which segregates to the outer grain region, increases the grain boundary resistivity resulting in a lowering of power loss.
\end{abstract}

\section{INTRODUCTION}

The miniaturisation of electronic devices demands a permanent increase of the driving frequency of switch mode power supplies. Therefore, reduction of the power loss of core materials at high frequency is an important challenge. The main motivation for using $\mathrm{MnZn}$ ferrites in transformer cores are their very low eddy current losses on account of the much higher electrical resistivity of ferrites in comparison to metals [2].

At higher operating frequencies, above $500 \mathrm{kHz}$, the contribution of the eddy current loss $\left(\mathrm{P}_{\mathrm{E}}\right)$ to the total loss is dominant. Thus, when the power loss of $\mathrm{MnZn}$ ferrites is to be decreased the suppression of the eddy current loss is of essential importance. To decrease $\left(P_{E}\right)$ successfully two key parameters must be modified; the average grain size (D) and the grain boundary resistivity $\rho_{\text {gr.b. }}[3,4]$. Average grain size can be decreased by selecting a sintering profile which includes a low concentration of oxygen in the sintering atmosphere [5]. On the other hand, the grain boundary resistivity can be effectively improved by doping the $\mathrm{MnZn}$ ferrite with aliovalent ions which segregate to the outer grain region [6]. In this contribution the combined effect of a low oxygen partial pressure and additions of $\mathrm{Ta}_{2} \mathrm{O}_{5}$ during sintering was studied.

\section{EXPERIMENTAL}

A ferrite powder of composition $\mathrm{Mn}_{0.66} \mathrm{Zn}_{0.27} \mathrm{Fe}_{2.07} \mathrm{O}_{4}$ with additions of $0.2 \% \mathrm{Ta}_{2} \mathrm{O}_{5}$ was prepared by the conventional ceramic processing method using chemical grade oxides. The average grain size of the ferrite powder after calcination and milling was about $1.5 \mu \mathrm{m}$. The powder was granulated and toroids were pressed to the dimensions $O D=22 \mathrm{~mm}, \mathrm{ID}=10 \mathrm{~mm}$, and $\mathrm{h}=5 \mathrm{~mm}$. Samples were sintered in a computer-driven furnace at a temperature of $1280^{\circ} \mathrm{C}$ for 4 hours. The samples labelled as $1,2,3$ and 4 were sintered at $20,10,5$ and 1 vol. $\%$ of oxygen, respectively, and were doped with 0.2 wt. $\% \mathrm{Ta}_{2} \mathrm{O}_{5}$. The samples labelled $a, b, c$ and $d$ were sintered at the same vol.\% of oxygen but they were not doped. The sintered samples were characterised; the density was measured, average grain size determined, and grain boundary resistance measured by the use of impedance spectroscopy. The power loss of the samples was determined at frequencies of $100,200,300,400,500$ and 700 $\mathrm{kHz}(50 \mathrm{mT})$ and $20^{\circ} \mathrm{C}, 60^{\circ} \mathrm{C}, 80^{\circ} \mathrm{C}$ and $100^{\circ} \mathrm{C}$ using a Clarke and Hass $258 \mathrm{~W}$ meter. $\mathrm{P}_{\mathrm{H}}$ and $\mathrm{P}_{\mathrm{E}}$ were obtained by extrapolating of the $P / f-f$ plots to $f=0$, where $f$ is the frequency.

\section{RESULTS AND DISCUSSION}

The power loss of samples doped with $0.2 \mathrm{wt} \%$ of $\mathrm{Ta}_{2} \mathrm{O}_{5}$ (A) and undoped samples (B) sintered at various oxygen concentrations is shown in Fig. 1. Samples 2, 3 and a, b, sintered at 10 and $5 \%$ of oxygen, respectively, exhibit the best magnetic properties, i.e. the lowest power loss. 


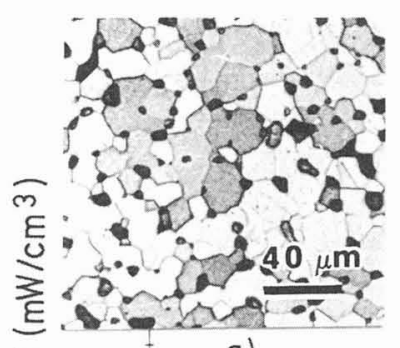

a)

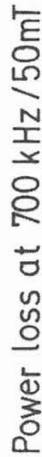

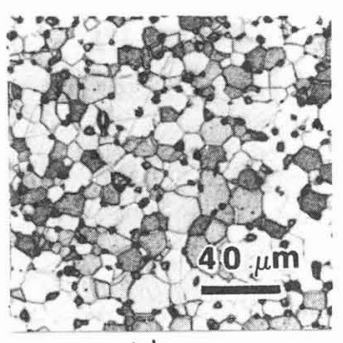

b)

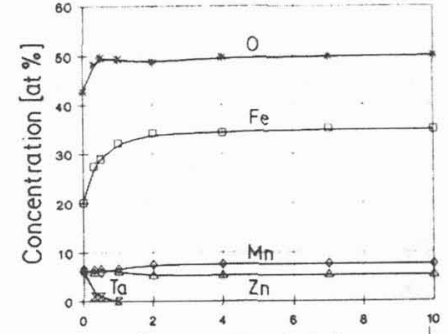

C) Sputter time $[\mathrm{min}]$

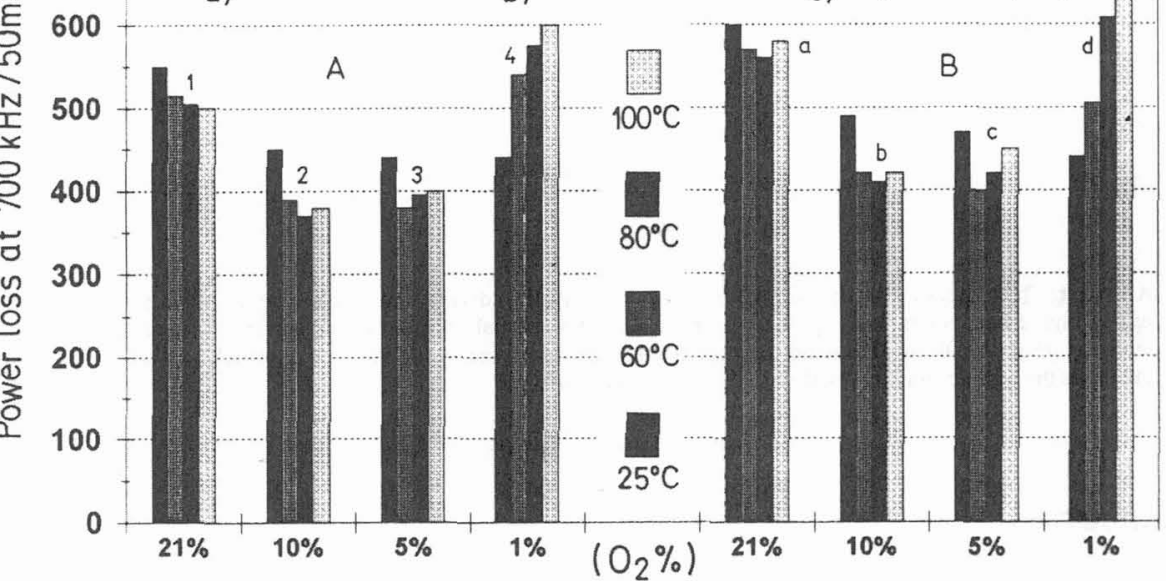

Figure 1a,b,c: Temperature dependence of power loss of samples sintered at various oxygen concentration (A) doped with $\mathrm{Ta} \mathrm{a}_{2} \mathrm{O}_{5}$ and (B) undoped, with typical microstructures of samples a) sintered at $21 \%$ of oxygen and b) sintered at $1 \%$ of oxygen. The insert $\mathrm{C}$ ) show the concentration depth profile obtained by AES of a doped sample.

Table I: Density $(\mathrm{p})$, thr. density (T.D.), average grain size $(\bar{D})$, grain boundary resistivity $\left(\mathrm{P}_{\mathrm{gr} . \mathrm{b}}\right)$, total loss $\left(\mathrm{P}_{\mathrm{v}}\right)$ and eddy current loss $\left(\mathrm{P}_{\mathrm{E}}\right)$.

\begin{tabular}{|c|c|c|c|c|c|c|c|c|c|c|c|}
\hline $\begin{array}{c}p \\
\left(g / \mathrm{cm}^{3}\right)\end{array}$ & $\begin{array}{l}\text { T.D. } \\
(\%)\end{array}$ & $\underset{(\mu \mathrm{m})}{\bar{D}}$ & $\begin{array}{c}\rho_{\mathrm{gb}} \\
(\Omega \mathrm{cm}) \\
\end{array}$ & $\begin{array}{c}\mathrm{P}_{\mathrm{E}} 80^{\circ} \mathrm{C} \\
\left(\mathrm{mW} / \mathrm{cm}^{3}\right)\end{array}$ & $\begin{array}{c}\mathrm{Pv} 80^{\circ} \mathrm{C} \\
\left(\mathrm{mW} / \mathrm{cm}^{3}\right)\end{array}$ & $\begin{array}{l}\text { Sample } \\
\text { Code }\end{array}$ & $\begin{array}{c}\rho \\
\left(\mathrm{g} / \mathrm{cm}^{3}\right)\end{array}$ & $\underset{(\mu \mathrm{m})}{\bar{D}}$ & $\begin{array}{c}\rho_{\text {g.b. }} \\
(\Omega \mathrm{cm})\end{array}$ & $\begin{array}{c}\mathrm{P}_{\mathrm{E}} 80^{\circ} \mathrm{C} \\
\left(\mathrm{mW} / \mathrm{cm}^{3}\right)\end{array}$ & $\begin{array}{c}\mathrm{P}_{\mathrm{V}}^{80} 0^{\circ} \mathrm{C} \\
\left(\mathrm{mW} / \mathrm{cm}^{3}\right)\end{array}$ \\
\hline 4.73 & 92.7 & $1 ? .3$ & 164 & 499 & 541 & $1, \mathrm{a}$ & 4.73 & 11.2 & 95 & 553 & 581 \\
\hline 4.75 & 93.1 & 10.4 & 153 & 352 & 387 & $2, b$ & 4.73 & 10.6 & 87 & 406 & 427 \\
\hline 4.77 & 93.5 & 9.1 & 145 & 362 & 390 & $3, c$ & 4.78 & 9.9 & 63 & 401 & 422 \\
\hline 4.82 & 94.5 & 8.1 & 151 & 534 & 576 & $4, d$ & 4.85 & 8.2 & 52 & 583 & 632 \\
\hline
\end{tabular}

The density of the samples increases on lowering the amount of oxygen in the sintering atmosphere, while the average grain size decreases. No significant differences in the average grain size were noted between doped and undoped samples; however, there is an essential difference in the grain boundary resistance. Samples doped with $\mathrm{Ta}_{2} \mathrm{O}_{5}$ exhibit an appreciably higher resisttivity (Table I). Typical microstructure of samples sintered at different partial pressures of oxygen is shown in Figs. $1 \mathrm{a}, \mathrm{b}$. From the results presented above, we can see that both a lowering ofthe oxygen concentration during sintering and doping of samples with $\mathrm{Ta}_{2} \mathrm{O}_{5}$, which segregates to the grain boundary (as can be seen from the conc. depth profile in Fig. 1c), lead to lower power loss. It can be shown that the eddy current loss depends on the ratio between the average grain size and the grain boundary resistivity [3,9]. At higher frequencies where the hysteresis loss can be ignored, the total loss $\mathrm{PV}_{\mathrm{V}}$ is therefore proportional to $\vec{D} / \mathrm{p}_{\mathrm{gb}}$. Thus, the beneficial influence of a low oxygen pressure during sintering and of the addition of $\mathrm{Ta}_{2} \mathrm{O}_{5}$ is mainly due to the formation of a fine microstructure and an increase of the grain boundary resistivity.

\section{References}

[1] Goldman A., Modern Ferrite Technology, New York; Van Nostrand (1990)

[2] Hendricks C.R. and Amarakoon V.W.R., Cer. Bull. 70(5) (1991) 817-813

[3] Drofenik M, J. Microelectron. Comp. and Mat., 24(1) (1994) 28-30

[4] Drofenik M. and Rozman M, Cer. Trans., 47 (1995) 287-293

[5] Znidaršic A and Drofenik M, IEEE Trans. Mag. 32(2) May 1996

[6] Znidaršic A, Limpel M and Drofenik M, IEEE Mag. 31(2) (1995) 950-53. 